\title{
Status of metal pollution in rivers flowing through urban settlements at Pune and its effect on resident microflora
}

\author{
Neelu Nawani ${ }^{1 *}$, Aminur Rahman ${ }^{2}$, Noor Nahar ${ }^{2}$, Anandakumar Saha ${ }^{3}$, \\ Balasaheb KAPADNIS ${ }^{4} \&$ Abul MANDAL ${ }^{2}$ \\ ${ }^{1}$ Microbial Diversity Research Centre, Dr. D. Y. Patil Biotechnology and Bioinformatics Institute, Dr. D. Y. Patil \\ Vidyapeeth, Pune-411033, India; e-mail: neelunawani@yahoo.com; neelu.nawani@dpu.edu.in \\ ${ }^{2}$ System Biology Research Centre, School of Biosciences, University of Skövde, SE-54128 Skövde, Sweden \\ ${ }^{3}$ Department of Zoology, University of Rajshahi, Bangladesh \\ ${ }^{4}$ Department of Microbiology, Savitribai Phule University of Pune, Pune - 411007, India
}

\begin{abstract}
This study illustrates the sporadic distribution of metals in fluvial systems flowing from catchments to urban settlements. This is a detailed study prognosticating the deteriorating quality of rivers at specific locations due to metal pollution. Heavy metals like cadmium, lead, nickel and mercury are prominent in industrial sector. Contour plots derived using spatial and temporal data could determine the focal point of metal pollution and its gradation. Metal values recorded were cadmium $157 \mathrm{mg} / \mathrm{L}$, lead $47 \mathrm{mg} / \mathrm{L}$, nickel $61 \mathrm{mg} / \mathrm{L}$ and mercury $0.56 \mathrm{mg} / \mathrm{L}$. Prokaryote diversity was less in polluted water and it harboured metal tolerant bacteria, which were isolated from these polluted sites. Actinomycetes like Streptomyces and several other bacteria like Stenotrophomonas and Pseudomonas isolated from the polluted river sites exhibited changes in morphology in presence of heavy metals. This stress response offered remedial measures as Streptomyces were effective in biosorption of cadmium, nickel and lead and Stenotrophomonas and Pseudomonas were effective in the bioaccumulation of lead and cadmium. The amount of $89 \mathrm{mg}$ of lead and $106 \mathrm{mg}$ of nickel could be adsorbed on one gram of Streptomyces biomass-based biosorbent. Such biological remedies can be further explored to remove metals from polluted sites and from metal contaminated industrial or waste waters.
\end{abstract}

Key words: metal pollution; bioremediation; morphological changes; bacteria; actinomycetes; Pune rivers; prokaryote diversity.

Abbreviations: AAS, atomic adsorption spectrophotometer; EC, electrical conductivity; ICP-MS, inductively coupled plasma mass spectrometer; IZ, industrial zone; NMDS, non-metric dimensional scaling; PAT, phylogenetic assignment tool; PCA, principal component analysis; SEM, scanning electron microscopy; SEM-EDS, scanning electron microscopy with energy dispersive X-ray spectroscopy; T-RFLP, terminal restriction fragment length polymorphism; UP, upstream.

\section{Introduction}

The most vital and valuable resource for human civilization is water. The livelihood of several people depends on rivers, which often become a development point for urban establishments and trade. The surface water is usually of good quality where it emerges, but seasonal variations, surface run-off, effluent discharges and other anthropogenic activities affect river water quality, composition and ecology. Several rivers are no longer able to provide drinking water due to natural and man-made variations introduced in physicochemical and biological properties of river ecosystems (Vorosmarty et al. 2010). Water pollution in both developing and developed countries has increased due to anthropogenic activities. A perpetual release of specific type of effluent allows few adaptable genera to predominate in that region. This process of "forced selection or evo- lution" disturbs the natural ecology and community structure. Pollution indirectly threatens the existence of several flora and fauna driving them towards extinction (Dudgeon et al. 2004). However, the natural ability of living beings to adapt to their environment often provides a solution to the problem.

Few of the major pollutants of water bodies are heavy metals, which are a serious threat to the health and well-being of humans and animals. In this study, we monitored the metal pollution in the rivers at Pune, where the surface waters are used by nearby dwellers for their household activities and cattle rearing or small scale agriculture. Use of metal polluted surface water is hazardous and appropriate remedial measures are required to decrease the metal content in these surface waters (PCMC 2013). Besides, it is important to evaluate the effect of metal pollution on bacterial diversity and if the inhabiting metal resistant strains can be used

\footnotetext{
* Corresponding author
} 
as remedial measures of clean-up. It was observed that there is probably a natural selection of metal resistant strains indicating long term exposure of these bacteria to the metals. Filamentous and non-filamentous bacteria, which demonstrated a significant change in morphology in response to the metals were chosen to determine their ability to adsorb, chelate or accumulate metals. The ability of these bacteria to remove metals from metal contaminated water promises a biological remedial measure for metal pollution.

\section{Material and methods}

\section{Study area and sampling}

Water samples were collected from rivers at Pune, where sampling locations were demarcated as upstream and downstream based on whether they were collected from respective catchment areas (upstream abbreviated as UP) or from the river flowing through the city (downstream abbreviated as IZ explaining the river stretches flowing through the industrial and nearby zones). Samples were collected roughly at a distance of $10 \mathrm{~km}$, in cases where river meandered distance was measured along the meandered course and not as a straight line. Mid stream samples were collected in triplicate in sterile containers at a depth of 0.3 metres in all the cases. All the samples were processed without prolonged storage. Where storage became necessary, the samples were kept at $4^{\circ} \mathrm{C}$ for not more than $36 \mathrm{~h}$.

\section{Physicochemical and metal analysis}

Each water sample was assessed for $\mathrm{pH}$, temperature, electrical conductivity (EC), chloride content, carbonates, bicarbonates, calcium, sodium, potassium and nitrate content (Eaton et al. 1995). The analyses were carried out immediately after collection of the samples to avoid any discrepancies. Total metal content in water sample or shallow sediments was determined using inductively coupled plasma mass spectrometer (ICP-MS), atomic adsorption spectrophotometer (AAS, Chemito AA203, India) and Computrace 797VA (Metrohm Ltd., Switzerland) system. Initially, analysis was carried out for metals like iron, nickel, lead, cadmium, mercury, zinc, copper, manganese, cobalt, boron, molybdate and strontium, and based on results obtained, further analysis were carried out only for metals, which were higher than permissible limit, i.e. nickel, cadmium, lead, mercury, and iron. For analysis of total metal content, the sample was treated with $30 \%$ nitric acid till $\mathrm{pH}$ 2.0. The sample was filtered through $0.22 \mu \mathrm{m}$ filter and used for analysis.

DNA extraction and terminal restriction fragment length polymorphism (T-RFLP)

Representative river water samples were subjected to microbial (prokaryote) community analysis. Total DNA was extracted from the concentrated water samples. The amount of $1.5 \mathrm{~mL}$ of sodium acetate $(3 \mathrm{M})$ and $33 \mathrm{~mL}$ absolute ethanol was added to $15 \mathrm{~mL}$ water sample to precipitate DNA. The cells were recovered by centrifugation at $10,000 \times g$ for $20 \mathrm{~min}$ at $4{ }^{\circ} \mathrm{C}$. The pellet was washed and re-suspended in $0.85 \% \mathrm{NaCl}$ and total DNA was extracted with SurePrep Water DNA Purification Kit (Fischer Bioreagents, USA). Quantitation of DNA was performed on a QubitTM Fluorometer (Invitrogen, USA). The bacterial 16S rRNA gene was amplified by PCR using the primer set $8 \mathrm{~F}$ and $1492 \mathrm{R}$ (8F: 5'-AGAGTTTGATCATGGCTCAG-3' and 1492R: 5'GGCTACCTTGCCACGACTTC-3) (Lane 1991). The 8F primer was labelled at the 5' end with HEX fluorescent dye. The PCR reaction contained $0.5 \mu \mathrm{L}$ of each primer $(10 \mathrm{mM})$, $5 \mu \mathrm{L}$ of the PCR buffer, $1 \mu \mathrm{L}$ of dNTP $(2.5 \mathrm{mM}), 0.5 \mu \mathrm{L}$ of Taq polymerase $(2.5 \mathrm{U} / \mu \mathrm{L})$ and double-distilled water for final reaction volume of $50 \mu \mathrm{L}$. PCR was performed at $95^{\circ} \mathrm{C}$ for $5 \mathrm{~min}$; 30 cycles of $95^{\circ} \mathrm{C}$ for $1 \mathrm{~min}, 55^{\circ} \mathrm{C}$ for $1 \mathrm{~min}$ and $72^{\circ} \mathrm{C}$ for $1 \mathrm{~min}$; and $72^{\circ} \mathrm{C}$ for $10 \mathrm{~min}$. PCR products were checked on $1 \%$ agarose gel and purified with the geneO-Spin PCR product Purification kit (GeneOmbio Technologies, India) according to the manufacturer's protocol. Appropriate controls were maintained during extraction and amplification.

Following PCR, $10 \mathrm{ng}$ of PCR products were digested with $0.5 \mathrm{U}$ of TaqI, AluI, HhaI restriction enzymes (New England Biolabs, MA) for $3 \mathrm{~h}$ at $37^{\circ} \mathrm{C}$ in $20 \mu \mathrm{L}$ reaction volume. The fluorescently labelled fragments were mixed with $9.7 \mu \mathrm{L}$ Hi-Di formamide (Applied Biosystems, USA) and $0.3 \mu \mathrm{L}$ GenScan $500 \mathrm{LIZ}$ Internal Size Standard. The mixture was denatured at $95^{\circ} \mathrm{C}$ for 3 min for inactivation of the restriction enzymes and immediately chilled on ice before loading. The samples were electrophoresed on 3130 Genetic Analyzer using the FA_36_POP-7 ${ }^{\mathrm{TM}}$ run module and G5 dye set.

\section{Data analysis}

Principal component analysis (PCA) was performed by using XLSTAT 2010 to identify the factors, which impacted each sample. The T-RFLP analysis for peak height and area, retention time and size in base pairs was done with reference to the internal standard using GeneMapper v3.5 (Applied Biosystems), GeneScan and Genotyper. The data was exported in Microsoft Office Excel program and subjected to multivariate analysis. The average number of fragments detected per sample and the number of fragments contained in the various size classes were determined. T-RFLP data was exported to create a binary data matrix using R-package (http://www.r-project.org) with the R-script for T-RFLP analysis (Abdo et al. 2006). This was used for the calculation of $\alpha$-diversity by determination of richness and diversity with indices like Dominance (D), Simpson (1-D), Shannon $(\mathrm{H})$ and Evenness $(\mathrm{E})$. All the diversity indices were determined from abundance data using PAST package. Phylogenetic assignment tool (PAT) was used to determine the community composition (Kent et al. 2003). Abundance data was subjected to non-metric dimensional scaling (NMDS) to create ordination plots in two dimensions, which could determine changes in the community with spatial variations and presence of metals. Other general graphical analysis was carried out using Surfer Version 10.7.972 and Microcal Origin Version 6.0.

Isolation of metal resistant bacteria and their stress response

The river water sample $1.0 \mathrm{~mL}$ undiluted was mixed with $20 \mathrm{~mL}$ molten Luria agar containing respective metal $(1 \mathrm{mM}$ and $3 \mathrm{mM}$ of cadmium, nickel, lead) and pour-plated. The plates were incubated at $37^{\circ} \mathrm{C}$ for $4-5$ days to isolate metal tolerant bacteria. Freshly isolated cultures were spot inoculated on Luria agar plates and incubated at $37^{\circ} \mathrm{C}$ for $3-$ 4 days. Plates with well developed colonies were overlayed with agar containing either cadmium $(1 \mathrm{mM})$, lead $(5 \mathrm{mM})$, nickel $(5 \mathrm{mM})$ or mercury $(0.05 \mathrm{mM})$. After $48 \mathrm{~h}$ incubation the plates were exposed to hydrogen sulphide gas for 1520 min, which forms light halos around colonies in case the metal is taken up. Exposure to hydrogen sulphide gas allows formation of metal sulphide resulting in a dark precipitate, where the metal is present. 
Deionized water with peptone $1 \%$ and yeast extract $0.3 \%$ and spiked with respective metal $(0.1 \mathrm{mM}$ mercury, $5 \mathrm{mM}$ iron, $5 \mathrm{mM}$ lead and 3 or $5 \mathrm{mM}$ nickel) was used to prepare agar medium. The amount of $10 \mu \mathrm{L}$ of $10^{6}$ spores $/ \mathrm{mL}$ or cells $/ \mathrm{mL}$ of metal tolerant bacteria were spot inoculated on these media to see the morphological variations induced in bacteria during growth in presence of metals. Morphology of actinomycetes and other nonfilamentous bacteria were recorded by scanning electron microscopy (SEM) on SEM-Jeol, model (JSM-6360, Jeol, Germany). Samples for SEM were prepared as described earlier (Prakash \& Nawani 2014).

\section{Metal removing ability of selected bacteria}

The bacteria (filamentous and non-filamentous), which showed characteristic changes in morphology in presence of metals were chosen to understand their metal remediation ability. The morphological changes induced by metals in bacteria were indicative of the ability of these isolates to survive in presence of metals.

Analysis of metals in metal contaminated water was carried out as explained before. Metal biosorption studies were carried out using vegetative cells of bacteria or mycelia of actinomycetes. The amount of $100 \mathrm{mg}$ of biomass was suspended in $10 \mathrm{~mL}$ of $5 \mathrm{mM}$ sterile lead, cadmium and nickel chloride solutions. Respective control suspensions either devoid of metal or cells were maintained. These were kept at $37^{\circ} \mathrm{C}$ with shaking maintained at $100 \mathrm{rpm}$. Separate suspensions were maintained for different time intervals $(0,2,4,6$, 8 and $24 \mathrm{~h}$ ). Incubation for respective flasks was terminated and biomass was separated by centrifugation at $5,000 \times g$ for $10 \mathrm{~min}$. The cell free supernatant was acidified with suprapure grade nitric acid to $\mathrm{pH} 2.0$ and then analyzed for residual amount of metal using the voltammetry system Computrace 797VA (Metrohm Ltd., Switzerland). Metal sorption on cells was confirmed by SEM with energy dispersive X-ray spectroscopy (SEM-EDS) or by Fourier transform infrared spectroscopy analysis of dried biomass. For testing metal accumulation ability, cells were grown in presence of $2.5 \mathrm{mM}$ cadmium or $5 \mathrm{mM}$ lead and the metal concentration in the cell free medium was monitored over duration of 6 days. The cells were collected by centrifugation at $5,000 \times g$ for $10 \mathrm{~min}$ and their morphology and metal accumulation on cell surface was analysed by SEM-EDS.

\section{Results and discussion}

\section{Physicochemical parameters and metal content}

The average values of all parameters evaluated for upstream and downstream regions of the rivers, the maximum and minimum values, and the standard deviation are given in Table 1. Standard deviation for upstream samples was lower than downstream samples. The study duration was 24 months and maximum, minimum and average values are indicated. In case of the rivers Mula, Mutha and their confluence, deviation for all parameters was observed, but the mean values were within permissible limits. The $\mathrm{pH}$ varied from 7.0 to 8.0 for all the samples and EC ranged from 0.1 to $1.7 \mathrm{~ms} / \mathrm{cm}$, which is in the recommended limits. Deviation was maximum for bicarbonate among all the parameters, and in general the deviation for all parameters was highest in samples obtained from Pavana
River indicating its exposure to variability was maximum. Most of the surface streams contain less than $200 \mathrm{mg} / \mathrm{L}$ carbonate and bicarbonate, and their high content occurs when the water has low calcium content (Nakayama 1969). Mean values of calcium were either equal or lower than the values recommended as general standards for discharge of environmental pollutants in all the rivers, although calcium is expected to be one of the most abundant cations in river water (GSR 801 (E) 1993). Calcium oxides and carbonates are frequently used for the precipitation of metal pollutants and very low concentration of calcium may increase the sodium absorption ratio making the water unfit for irrigation. Nitrate content was high in downstream regions of the rivers Indrayani, Pavana and Mula, justifying the presence of pollutants, which could be in form of fertilizers or industrial effluents. Usually domestic sewage and agricultural wash-offs have higher content of nitrates or other nitrogenous compounds (Sunderay et al. 2006). Chloride content was within the recommended limits and formed one of the major inorganic ions in river water. Average potassium content was high in all the rivers; generally it contributed by natural minerals, fertilizers, medicines and paper production. Presence of such industries in vicinity of the rivers points towards the possibility of effluent seepage.

In the case of metals, iron and strontium were in permissible limits except at one or two locations. However, the levels of cadmium, nickel, lead and mercury were higher than permissible limits, the maximum observed in downstream locations near the industrial zones. Cadmium is closely associated with zinc and lead in the environment, which explains the co-occurrence of lead and cadmium in several industrial zones (ATSDR 2008). Local boating and fishing activities are a cause of metal leaching from antifouling paints used to protect boat keels and hulls. Cadmium and lead are frequently used in antifouling paints in recent years as an alternative to tributyltin (Yebra et al. 2004). Increase in cadmium, lead and nickel content could be due to several small scale battery manufacturing units, paint units and other industries generating metal waste. It could also possibly be due to leaching of metals from the sediments, where deposition may be present. Overall, heavy metal content was much higher than the permissible limit in rivers Pavana and Indrayani in the downstream sections near the industrial zones, whereas metal pollution was not highly prominent in Mula and Mutha Rivers and their confluence. Land-fill may also have contaminated water sources.

We identified the foci or origins of these metal pollutants in the Pavana and Indrayani Rivers (Fig. 1AD). The contours plotted in range of $18^{\circ} 25^{\prime}$ to $18^{\circ} 45^{\prime}$ $\mathrm{N}$ and $73^{\circ} 30^{\prime}$ to $73^{\circ} 55^{\prime}$ E show the sites, where the levels of cadmium, lead, nickel and mercury were highest, which helped in understanding the origin point of the pollutants as well as their gradient across the rivers. Two point sources identified for cadmium pollution, which decreased radially with distance, are referred to as IZ1 Pavana M8 and IZ2 Indrayani M8. Similarly, 
N. NAWANI et al.

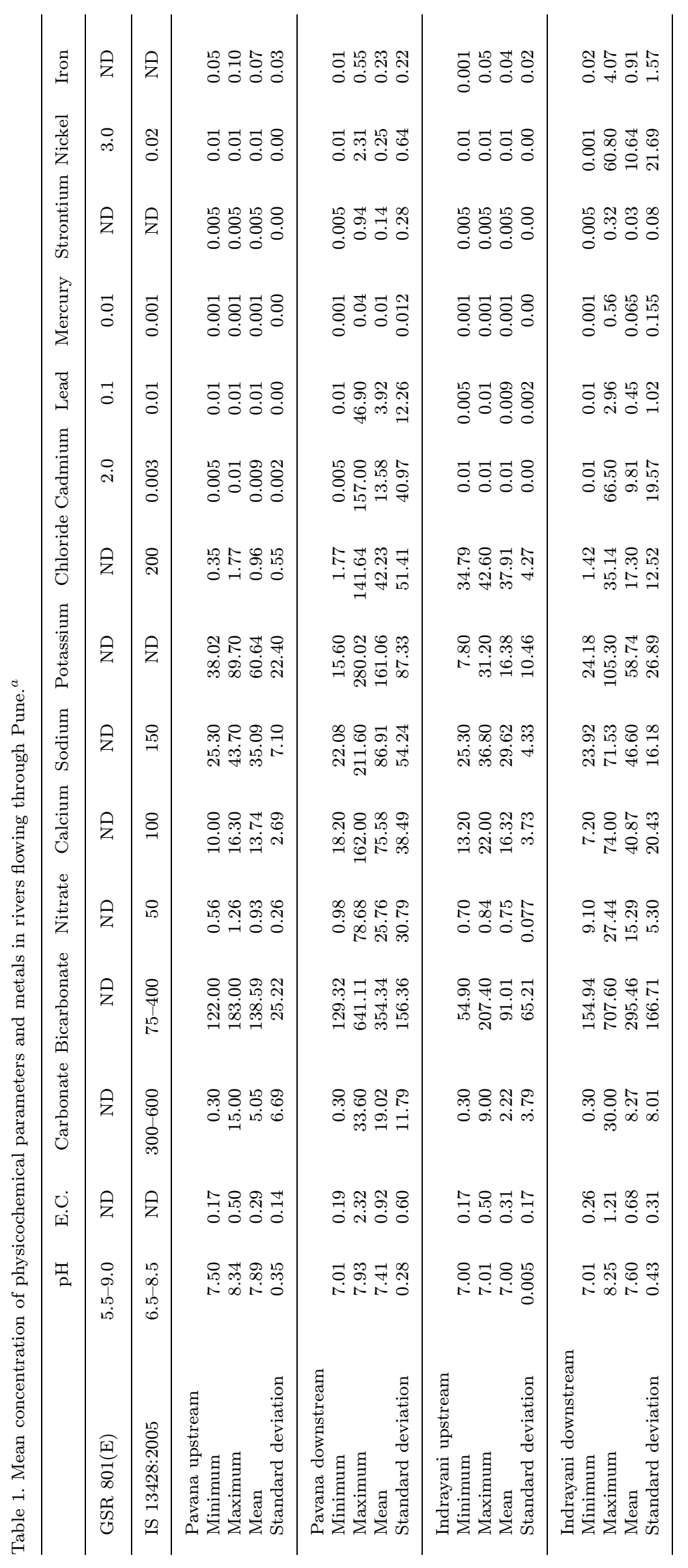




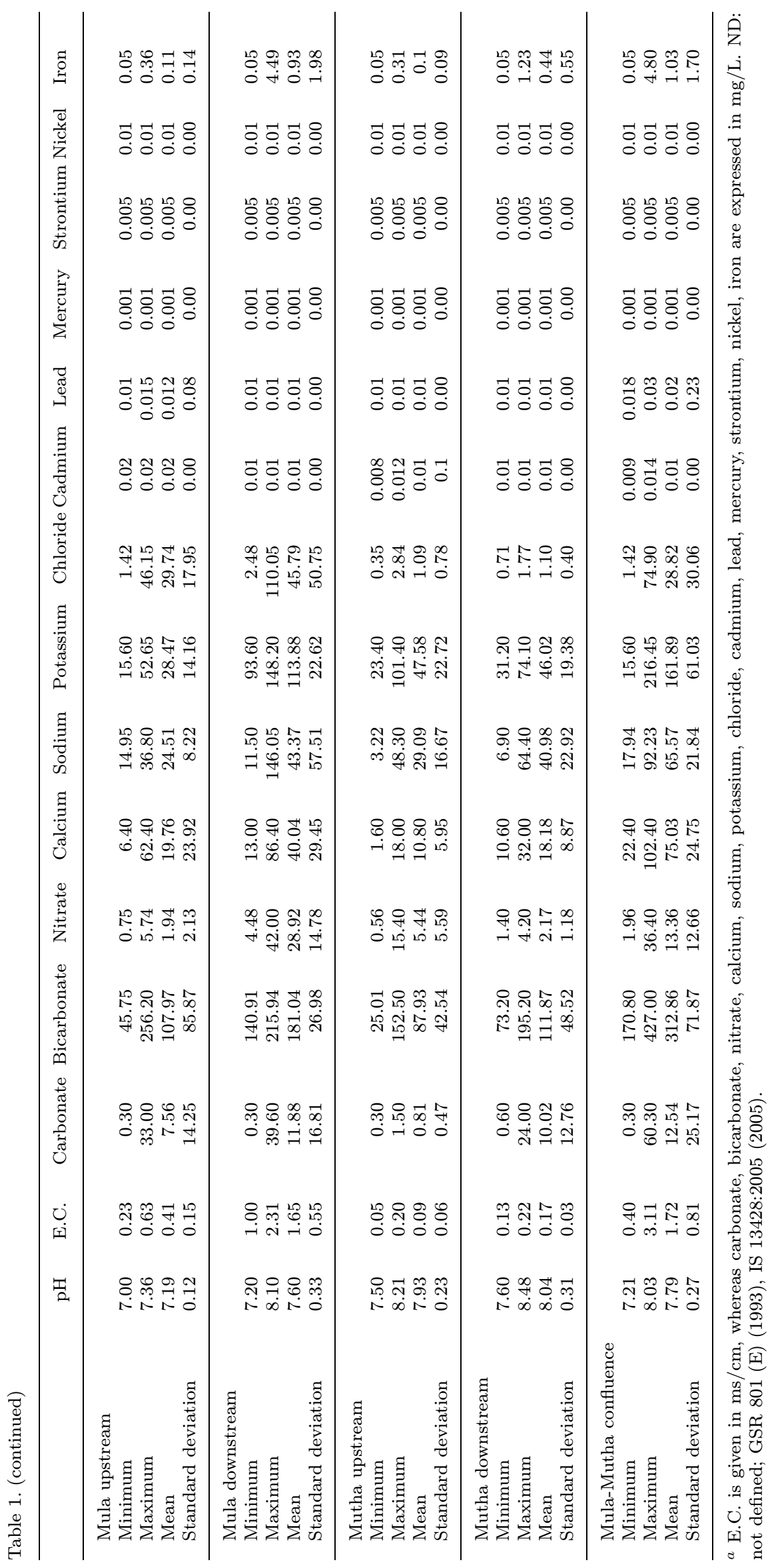




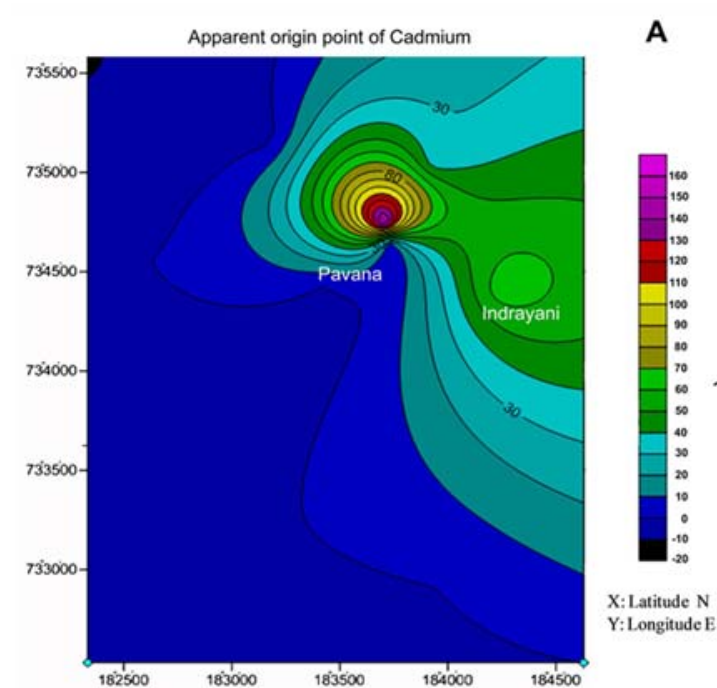

A Apparent origin point of Mercury

C
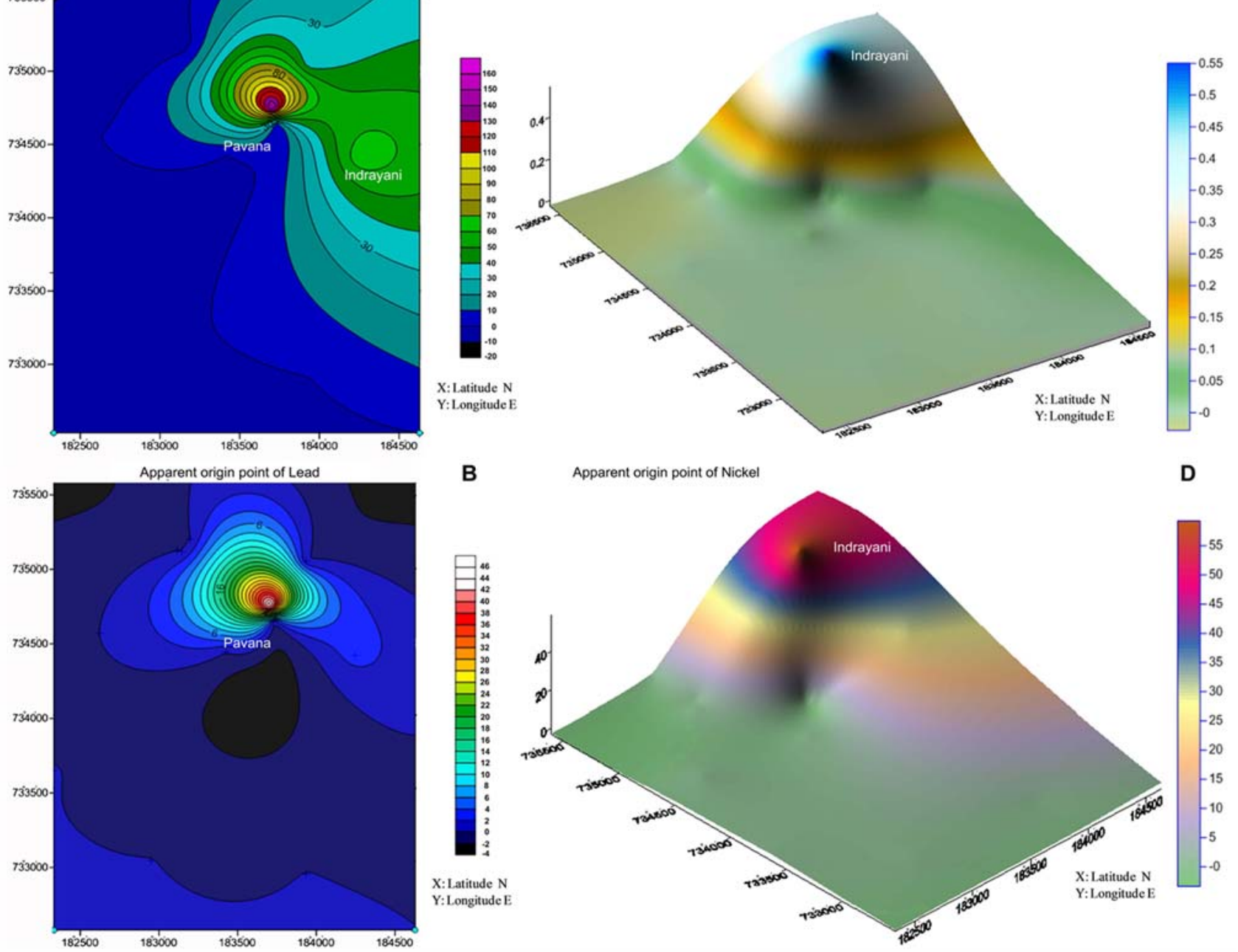

Fig. 1. Contour plots indicating the apparent origin of cadmium (A), lead (B), mercury (C), and nickel (D) in the rivers flowing through Pune and the gradation of metals.

lead pollution seems to originate at the same point IZ1 Pavana M8, which coincides with the origin of cadmium pollution. The focal point of metal pollution at river Indrayani coincides with that of river Pavana with a distance of nearly $15-20 \mathrm{~km}$, explaining that both rivers may be contaminated from similar source of pollution. The sites IZ2 Indrayani M8 and IZ3 Indrayani M8 showed maximum nickel pollution. Thus IZ1 Pavana M8 site had higher levels of cadmium and lead, IZ2 Indrayani M8 had higher levels of cadmium and nickel, and IZ3 Indrayani M8 had highest levels of nickel and mercury; cadmium was also high but lesser than the levels found at IZ1 Pavana M8 and IZ2 Indrayani M8. The high levels of metals indicate multiple factors contributing to the pollution including industrial activities and sediment leaching. Metals can get deposited in the sediment with organic matter with continuous discharge in the river bodies and may leach out into the water as free ions. The upstream water samples had no signs of metal pollution.

\section{Impact on prokaryote diversity}

In order to understand and further locate an in situ remedial measure, prokaryote diversity was evaluated in the river samples. The types of phyla predominant in samples with highest pollution were compared with upstream samples taken as controls. The samples considered for T-RFLP analysis included those with highest levels of metals (IZ1 Pavana M8, IZ2 Indrayani M8, IZ3 Indrayani M8), upstream water samples (UP Pavana M8, UP Indrayani M8) and one sample (IZ2 Pavana M8) near vicinity of a representative polluted site like IZ1 Pavana M8. T-RFLP analysis could identify the phyla associated in the representative samples as shown in Figure 2. The phyla Proteobacteria $>$ Firmicutes $>$ Bacteriodetes $>$ Actinobacteria predominated all the samples than other phyla. Upstream samples had similar phyla, but the number of genera seemed to be higher in them as compared to IZ samples with metal contamination. IZ2 Pavana M8 site, which was located near the polluted site also depicted variations in prokaryote diversity, which indicates an indirect effect of metal pollution on the nearby regions. Presence of Bacteriodetes suggests a discharge of sewage in the rivers. Dominance by Proteobacteria and reduction in Actinobacteria is reported for soils contaminated with chromium and ar- 

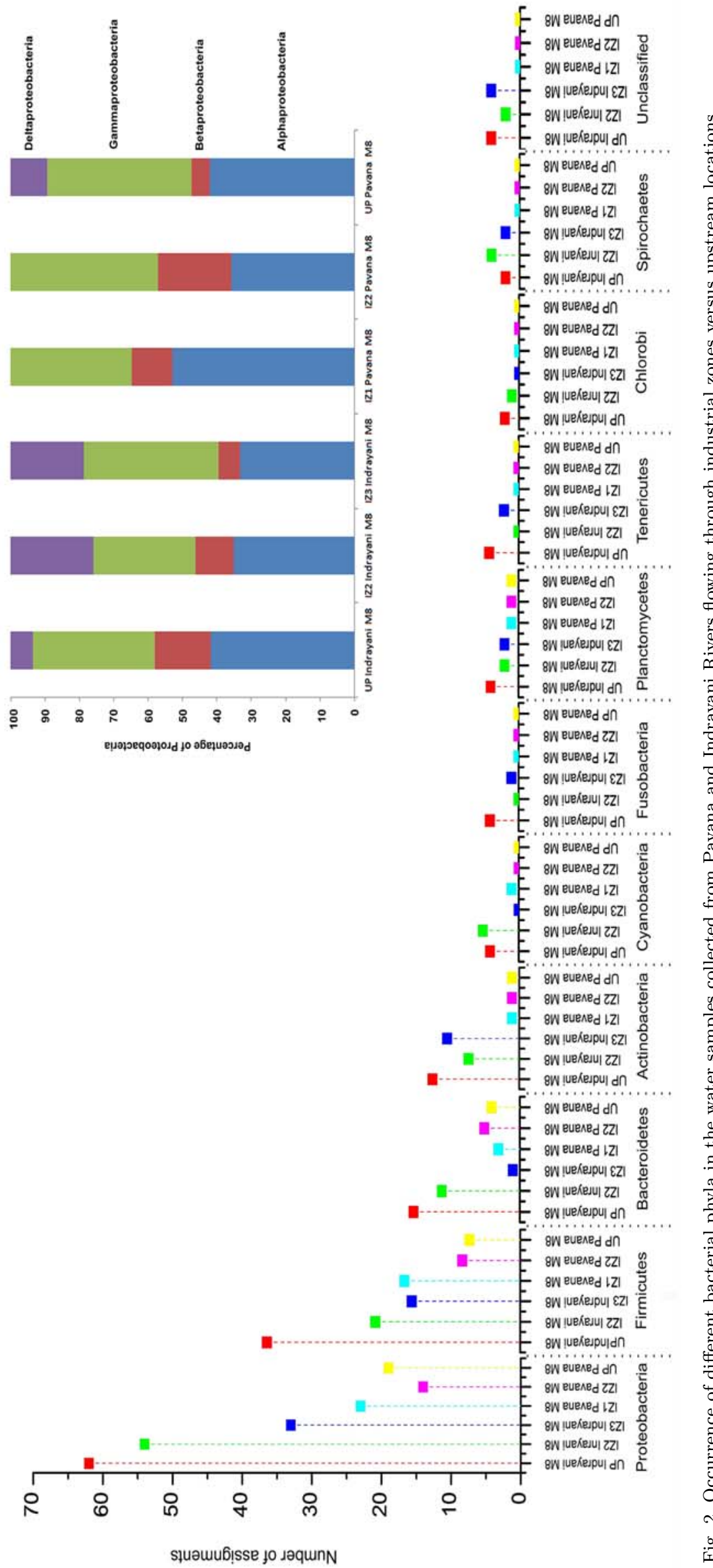
Table 2. Diversity indices (prokaryote) of six representative samples from Indrayani and Pavana rivers.

\begin{tabular}{lcccccc}
\hline Index & UP Indrayani M8 & IZ2 Indrayani M8 & IZ3 Indrayani M8 & IZ1 Pavana M8 & IZ2 Pavana M8 & UP Pavana M8 \\
\hline Dominance (D) & 0.14 & 0.29 & 0.25 & 0.55 & 0.70 \\
Simpson (1-D) & 0.86 & 0.71 & 0.75 & 0.45 & 0.30 \\
Shannon (H) & 2.02 & 1.29 & 1.49 & 0.81 & 0.48 \\
Evenness (E) & 0.94 & 0.91 & 0.88 & 0.74 & 0.81 \\
\hline
\end{tabular}

senic, which is similar to the results in this study (Sheik et al. 2012). Exposure to pollutants and dominance of a particular group explains their adaptability and evolution of survival measures (Barkay \& Pritchard 1998).

The Shannon's index $(\mathrm{H})$ for IZ2 Indrayani M8 was nearly half of the index for upstream UP Indrayani M8 implying less number of species in downstream samples (Table 2). Similarly, value of $\mathrm{H}$ for UP Pavana M8 is more than that for IZ2 Pavana M8, indicating the number of species is less in polluted site. Evenness (E) for UP Indrayani M8 sample is near 1.0, but it decreases for IZ downstream samples, suggesting predominance of a particular species. The E values for river Pavana are not close to 1.0, but are nearly similar for both upstream and downstream samples from this river due to fewer species and divergence of relative abundance from evenness. Simpson's index of diversity (1-D) is highest for UP Indrayani M8 and is lower in IZ Indrayani samples. In conclusion, river Indrayani has more diversity than river Pavana, which can be corroborated by dominance indices. Similar effects and reduction in diversity was observed in soil microbial communities exposed to cadmium (Muhammad et al. 2005). Dominance (D) values for Pavana samples are larger, which means particular phyla predominate, whereas smaller values of dominance were seen for samples from Indrayani River indicating more diversity. This is also seen in Figure 2, where samples from Pavana River are predominated by few phyla correlating with dominance. In samples from Indrayani River, Proteobacteria and Firmicutes are predominant followed by other phyla, like Bacteroidetes, Actinobacteria and Cyanobacteria.

The NMDS ordination of spatial variations in prokaryote community structure is based on abundance of phyla and their types in the samples when metal content was highest. NMDS is based on proximity matrix where optimally scaled proximities are reflected as disparities. Figure 3A compares the sites based on prokaryote diversity. Each point represents the station or site, from where the sample was collected and distance between the points indicates similarity in terms of prokaryote community. Samples from Pavana River differ from those collected from Indrayani River based on the fact that the second dimension is primarily contributed by samples from upstream and downstream samples of Indrayani River and the first dimension is contributed by samples from Pavana River. Figure 3B indicates station similarities influenced by presence of metals, where mixed influence is seen on samples from both rivers. Dimension 1 is contributed mainly by cadmium followed by lead, whereas dimension 2 is con- tributed by several similar level factors. The difference between original matrices and ordination data was measured in terms of stress value, which is considered acceptable if less than 0.1. Kruskal's stress (Stress 1) is 0.026 for station wise ordination (Fig. 3C) and 0.042 for metal and phyla based ordination (Fig. 3D) indicating the goodness of fit to range from good to excellent (Kruskal 1964a,b). The Shepard diagrams exhibit less spread, hence a good fit.

PCA gave the relation between the sampling sites, prokaryote diversity and occurrence of metals. UP Indrayani samples were significantly different from IZ2 and IZ3 Indrayani samples. Both IZ2 and IZ3 Indrayani appear to be related to each other in terms of bacterial diversity (Fig. 4). IZ1 Pavana M8 is significantly different than UP Pavana M8 and IZ2 Pavana M8 samples. No overlap in samples from Indrayani and Pavana Rivers was seen indicating both the rivers differ in their bacterial indices. Cadmium, lead, strontium and mercury appear to correlate with IZ1 Pavana M8 with cadmium being the most influencing factor. However, absence of phyla in the quadrant marks the influence of these factors on the survival or selectivity of bacteria. One of the causes for increased exposure to the metal is stagnation of water; such shifts in bacterial community with seasons, pollutants and other variables have been reported previously (Dang et al. 2010, Cao et al. 2012). The polluted sites fall on the right of Factor 2 axis along with metals, which strongly suggests the decrease in the diversity. A negative correlation is clear from the projection of metals in the quadrant diagonally opposite to the quadrant representing intersection of $\mathrm{F} 1$ and F2, where most of the phyla are placed. The total variance of $64 \%$ is contributed by Factor 1 and Factor 2, where $41.2 \%$ is positively contributed by Factor 1 . The most polluted site is the IZ1 Pavana M8 followed by IZ2 Indrayani M8 and IZ3 Indrayani M8. The IZ1 Pavana M8 sample exhibits least diversity, which could be due to the selection of phyla, which can grow in the presence of metals found at these sites. Since the metals were detected in the pre-monsoon and monsoon months, the bacteria are exposed to the metals for nearly $50 \%$ of the annual period. Based on the bacterial diversity data and foci of metal pollution, bacteria that could tolerate metals were isolated from IZ1 Pavana M8, IZ2 Indrayani M8 and IZ3 Indrayani M8 samples.

Isolation of metal resistant bacteria and morphological changes in presence of metals

Several bacteria including actinomycetes could be isolated from IZ1 Pavana M8, IZ2 Indrayani M8 and IZ3 

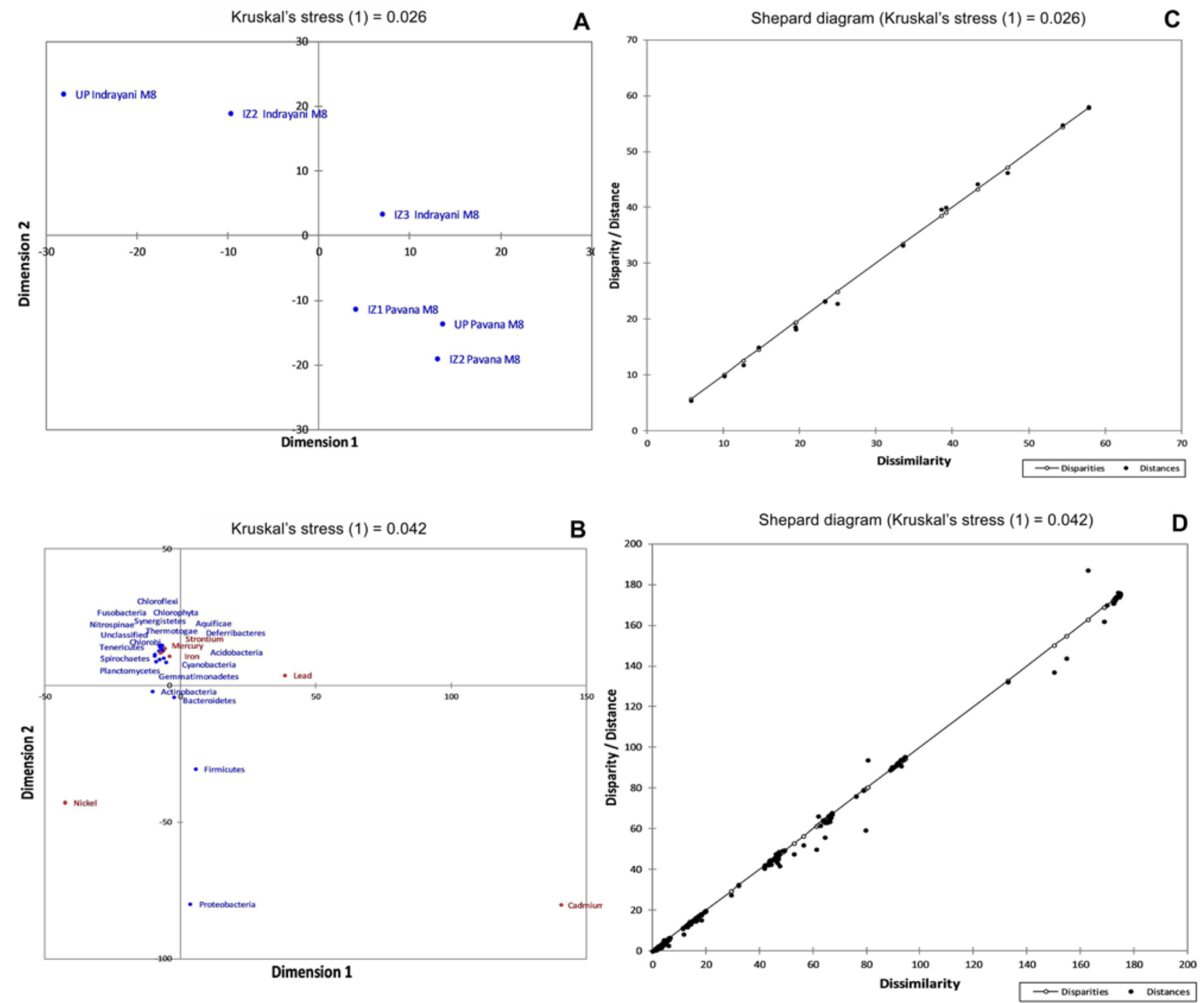

Fig. 3. Nonmetric multidimensional scaling ordination of sampling stations based on bacterial diversity (A); effect of metals on possible occurrence of different phyla (B); Shepard plot for data in A (C); and Shepard plot of data in B (D).

Indrayani M8 samples in presence of cadmium, nickel and lead. In presence of mercury, not many strains could be isolated. Figure 5A shows the bacteria (including actinomycetes) that could grow on Luria agar with respective metal after 4 days of incubation and Figure $5 \mathrm{~B}$ shows the bacteria grown on Luria agar with respective metals and later exposed to $\mathrm{H}_{2} \mathrm{~S}$ or $\left(\mathrm{NH}_{4}\right)_{2} \mathrm{~S}$. As seen (Fig. 5), representative bacteria and actinomycetes can grow in presence of metals and some of them appear to accumulate metals, as evident from the clearance around the colony.

In order to see the suitability of these bacteria to be used for removal of metals, the morphology of filamentous and non-filamentous bacteria was studied in presence of metals. Figure 6 shows the change in morphology of actinomycetes isolated from polluted sites. As seen from Figure 6A-F, Streptomyces sp. P27 isolated from IZ1 Pavana M8 exhibits distinct changes in morphology in presence of metals. In absence of any metal, the spores appear to have a smooth texture; they have no spines and are well separated with septation evident in the mycelium. However, in presence of $0.1 \mathrm{mM}$ mercury and $1 \mathrm{mM}$ cadmium, the septation is lost, the mycelia and spores cannot be differentiated and the texture is rough and rugose. In presence of $5 \mathrm{mM}$ iron, lead and nickel the septation was seen, spores could be differentiated from mycelia, however, the spores lost their smooth texture instead developed spines. However, the actinomycetes isolated from IZ2 Indrayani M8, Streptomyces sp. I167 did not exhibit major morphological changes at the same concentrations of metal as tested for Streptomyces sp. P27. Figure 6G-L shows the growth of Streptomyces sp. I167 in absence of metals (Fig. 6G) and presence of $(\mathrm{H}) 0.1 \mathrm{mM} \mathrm{Hg}$, (I) $1 \mathrm{mM} \mathrm{Cd}$, (J) $5 \mathrm{mM} \mathrm{Fe},(\mathrm{K}) 5 \mathrm{mM} \mathrm{Pb}$, and (L) $5 \mathrm{mM} \mathrm{Ni}$. This differential morphological response of strains although from the same genus could be attributed to their exposure to variable amount of metals. Metal content at IZ1 Pavana M8 was much higher than IZ2 Indrayani M8, due to which Streptomyces sp. P27 may have developed better adaptive strategies to adsorb or accumulate metals; also the actinomycetes community appeared to be less diverse at IZ1 Pavana M8. Morphological alterations in presence of copper have been reported earlier in acti- 
Biplot (axes F1 and F2: $64.07 \%$ )

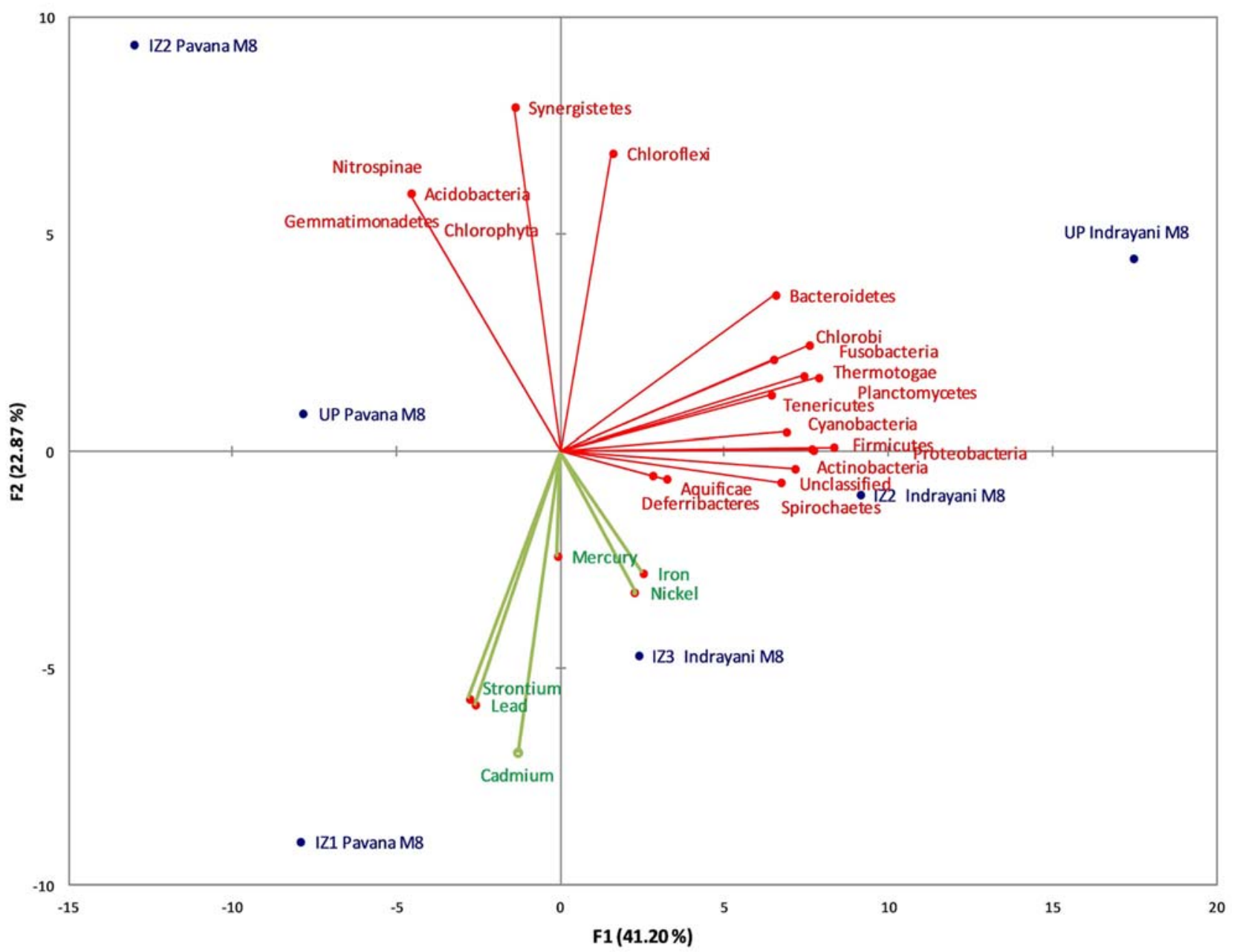

Fig. 4. Principal component analysis to determine the spatial and temporal effect of metals on bacterial diversity in Pavana and Indrayani Rivers.
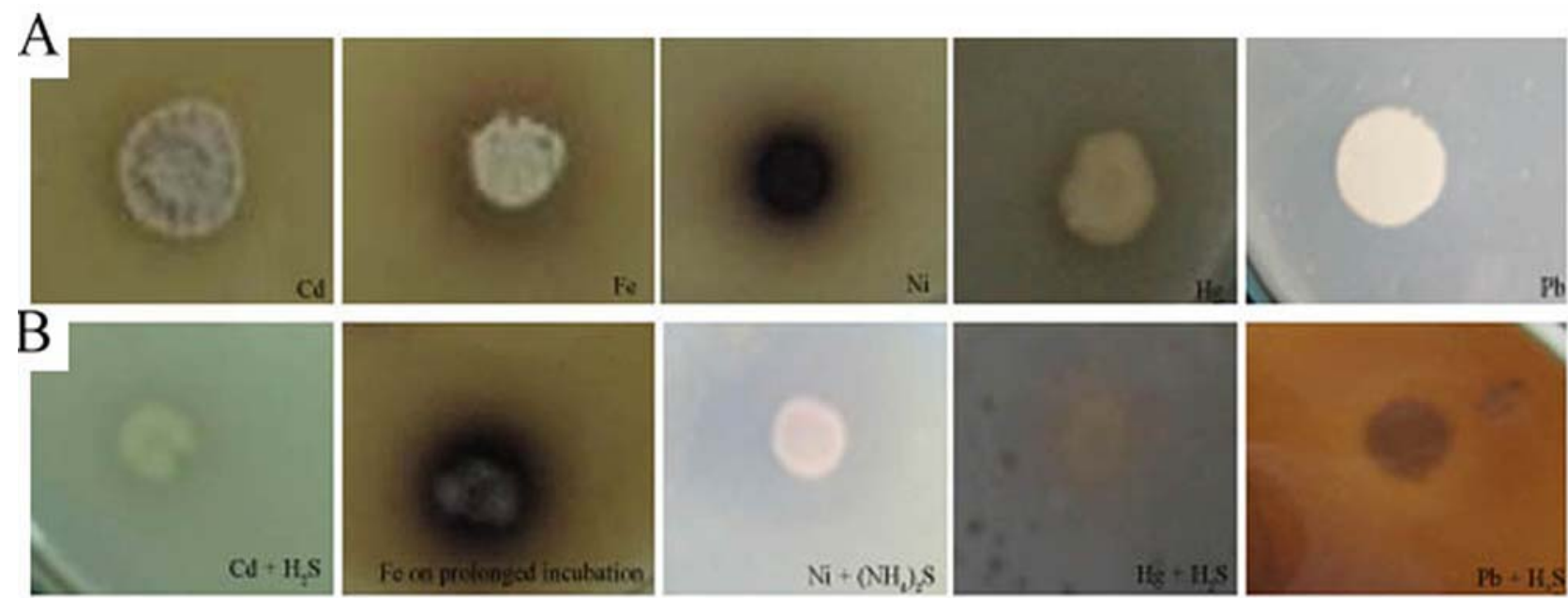

Fig. 5 Growth of representative isolates (bacteria and actinomycetes) obtained from polluted sites on (A) Luria agar with $1 \mathrm{mM}$ of respective metal as indicated after 4 days of incubation, and (B) bacterial colonies overlayed with agar with respective metals and later exposed to $\mathrm{H}_{2} \mathrm{~S}$ or $\left(\mathrm{NH}_{4}\right)_{2} \mathrm{~S}$, as indicated.

nomycetes like Streptomyces sp. and Amycolatopsis tucumanensis, where mycelia structures are completely distorted for sensitive strains, whereas in case of re- sistant strains, morphological alterations are evident (Dávila Costa et al. 2011).

Streptomyces sp. P27 was tested for its ability to 

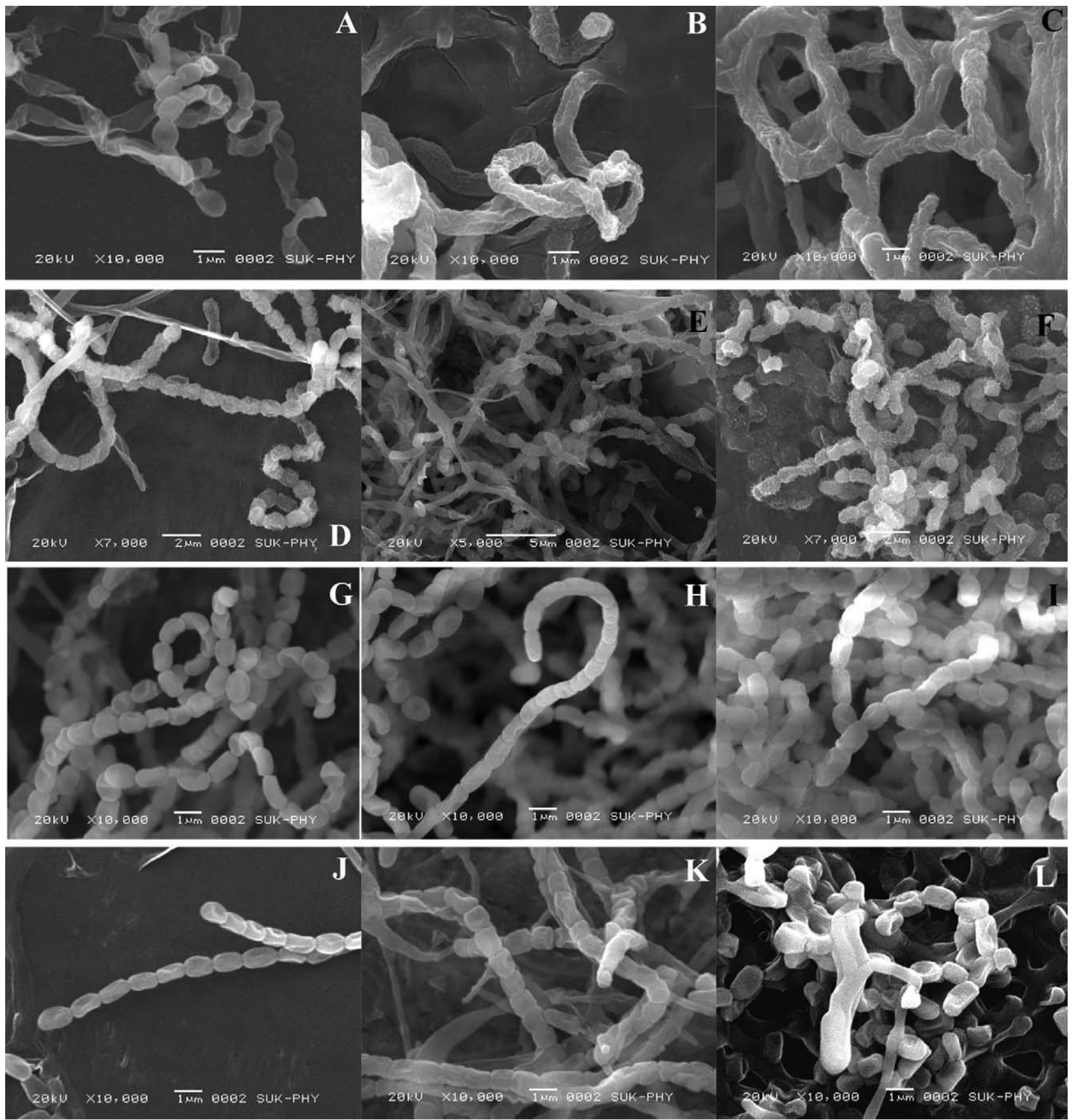

Fig. 6. Streptomyces sp. P27 isolated from IZ1 Pavana M8 grown in absence of metal (A), Streptomyces sp. P27 grown in presence of $0.1 \mathrm{mM}$ mercury (B), $1 \mathrm{mM}$ cadmium (C), $5 \mathrm{mM}$ iron (D), $5 \mathrm{mM}$ lead (E), and $5 \mathrm{mM}$ nickel (F). Streptomyces sp. I167 isolated from IZ2 Indrayani M8 in absence of metals $(\mathrm{G})$ and presence of $0.1 \mathrm{mM}$ mercury $(\mathrm{H}), 1 \mathrm{mM}$ cadmium $(\mathrm{I}), 5 \mathrm{mM}$ iron $(\mathrm{J}), 5 \mathrm{mM}$ lead $(\mathrm{K})$, and $5 \mathrm{mM}$ nickel $(\mathrm{L})$.

adsorb metals (Fig. 7A), when the biomass was suspended in $5 \mathrm{mM}$ metal solution (nickel, cadmium and lead); the amount of metal in the cell free solution decreased with time. This was confirmed by the Fourier transform infrared spectroscopy analysis of the biomass exposed to nickel, lead and cadmium (Fig. 7B); the control cells being not exposed to any metal. Cells exposed to cadmium gave similar spectrum as that of cells, which were not exposed to any metal, hence is not depicted here. The spectrum with nickel shows characteristic bend at $1,060 \mathrm{~cm}^{-1}$ that could be due to interaction of the metal with surface phosphate groups.
For the spectrum with lead, the characteristic bend at $1,380 \mathrm{~cm}^{-1}$ and $1,040 \mathrm{~cm}^{-1}$ could be due to interaction of metal with surface nitrogen and phosphates, respectively. The band at $2,900 \mathrm{~cm}^{-1}$ is contributed by $\mathrm{C}-\mathrm{H}$, at $1,660-1540 \mathrm{~cm}^{-1}$ could be due to the $\mathrm{C}=\mathrm{O}$ and amide groups, and at 1,400-1,380 $\mathrm{cm}^{-1}$ could be due to $\mathrm{N}-\mathrm{H}$ bending in the amine groups. This indicates the involvement of cell surface hydroxyl, amine, nitrate and phosphate groups in the adsorption of metals. The amount of $89 \mathrm{mg}$ of lead and $106 \mathrm{mg}$ of nickel could be adsorbed on one gram of Streptomyces biomass-based biosorbent. Several fungi have been used as material for 

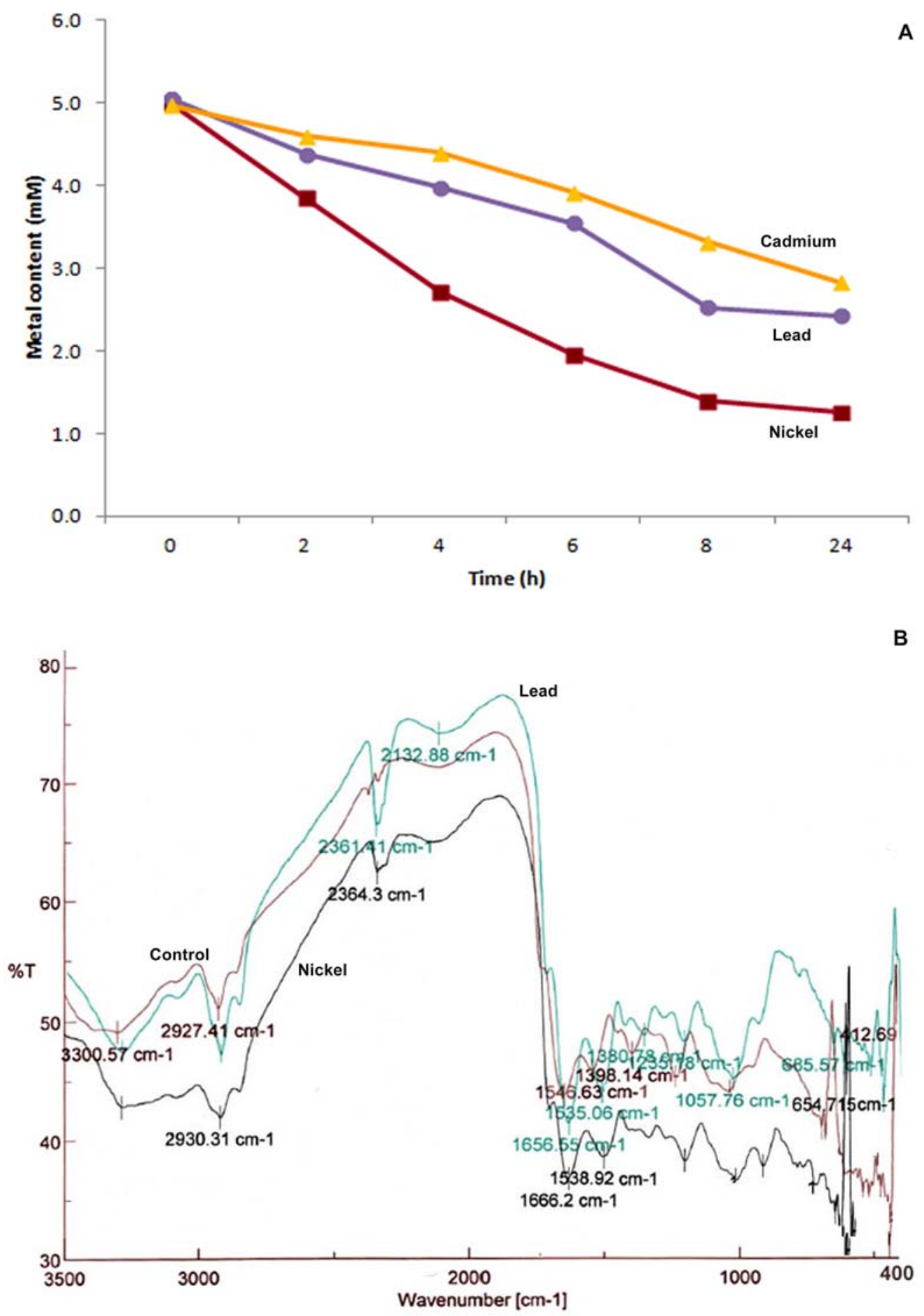

Fig. 7. (A) Sorption of metals on biomass of Streptomyces sp. P27. Residual amount of nickel, lead and cadmium in the cell free solution, in which initial metal concentration was $5 \mathrm{mM}$. (B) FT-IR spectra of biomass expected to adsorb metals on the cell surface. Spectrum for cadmium was same as the cells not exposed to metals; control indicates cells not exposed to any metal.

the biosorption of heavy metals, like lead and copper with nearly $54 \mathrm{mg}$ lead adsorbed per gram of biomass, indicating the potential of metal biosorption in mycelial cultures (Iskandar et al. 2011).

From IZ3 Indrayani M8 sample, Pseudomonas sp. IZC3 and Stenotrophomonas sp. IZL3 were isolated and they exhibited maximum tolerance towards cadmium and lead, respectively, although this sample had higher levels of cadmium, nickel and mercury. Occurrence of metal resistant proteobacteria is expected in this sample, which correlates well with the community analysis. Figure 8A-I shows the changes in cellular morphology, the amount of metal on cell surface and residual metal concentration in the medium inoculated with Pseudomonas sp. IZC3 and Stenotrophomonas sp. IZL3. In general, the cells tend to accumulate the metals particularly in the case of Pseudomonas sp. IZC3, where cadmium accumulation or aggregation is clearly visible. 

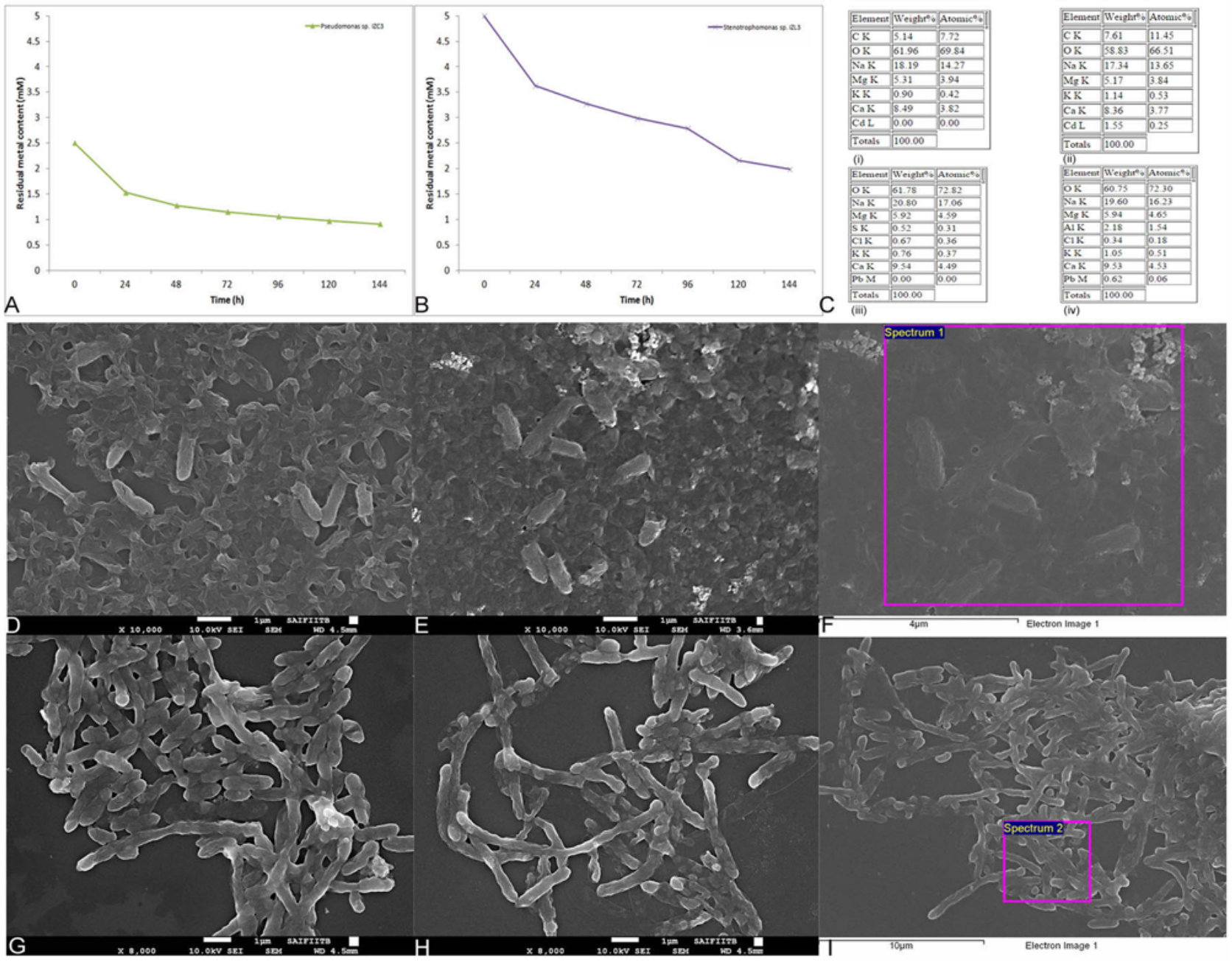

Fig. 8. Accumulation of metals by growing cells of Pseudomonas sp. IZC3 and Stenotrophomonas sp. IZL3 (A) residual concentration of cadmium in medium inoculated with Pseudomonas sp. IZC3; (B) residual concentration of lead in medium inoculated with Stenotrophomonas sp. IZL3; (C) estimation of metals on Pseudomonas sp. IZC3 cells grown in (i) absence of cadmium and (ii) presence of $2.5 \mathrm{mM}$ cadmium and estimation of metals on Stenotrophomonas sp. IZL3 cells grown in (iii) absence of lead and (iv) presence of $5 \mathrm{mM}$ lead; SEM of Pseudomonas sp. IZC3 cells grown (D) in absence of cadmium (E) in presence of $2.5 \mathrm{mM}$ cadmium (F) SEM-EDS spectrum for determining cadmium concentration present on cell surface as indicated in C(ii) in this figure; SEM of Stenotrophomonas sp. IZL3 cells grown $(\mathrm{G})$ in absence of lead $(\mathrm{H})$ in presence of $5 \mathrm{mM}$ lead (I) SEM-EDS spectrum for determining lead concentration present on cell surface as indicated in $\mathrm{C}(\mathrm{iv})$ in this figure.

The scanning spectrum of cell surface shows distinct difference in the cells grown in presence and absence of the metals. Our results suggest that metal resistance may result from a sequestration or binding mechanism. Lead is reported to bind to polysaccharides or proteins on the cell surface (Levinson \& Mahler 1998). Several bacteria are reported to accumulate lead on cell surface and within the cells (Golab et al. 1990). Accordingly, we have reported the use of biomatrices of bacterial biomass, which can be used to adsorb the metals from water bodies or industrial effluents. Pre-treatment of industrial effluents for the removal of metals will decrease the pollution. The use of bacterial biomatrices, which have bacteria entrapped in a matrix will ensure that microbial load on the river is not increased (Nawani et al. 2016).

The limitation of resources and the demand for potable water suggest river systems as an alternative natural asset. The integration of river basins in In- dia, which is already in progress, will provide the much needed "alto rilievo" to meet the water requirements. However, it must be ensured that water quality of significant river basins must not be compromised due to unchecked pollution making human and animal life a victim to industrial menace.

This study clearly demonstrates the presence of harmful pollutants at some sites in rivers. Statistical inferences are convincing enough to reckon that anthropogenic activities are a major cause for this pollution. Further, presence of heavy metals has decreased the natural prokaryote diversity, which is clear when the water samples from catchment areas are compared with those obtained from course of river through industrial zones. Diversity indices correlate a decrease in diversity with poor water quality making it difficult to anticipate the status of natural ecology after few years if the pollution is not controlled and prevented. A decrease in average rainfall will worsen the situation as more peo- 
ple will depend on river water for their daily activities. A continuous assessment of river water quality indices is the most immediate action necessary for framing effective restoration measures. Interestingly, bacteria from the polluted sites seem to provide a remedy to curb this metal pollution due to their ability to survive in presence of metals. This indicates an adaptive feature of bacteria, due to which they tend to either accumulate or adsorb the metals on cell surface. These kinds of metal-responsive bacterial cells can be used to remove the metals from contaminated sites and thus provide a biological low-cost remedial measure to handle metal wastes or pollution.

\section{Acknowledgements}

This work was supported by the financial grant from Swedish International Development Cooperation Agency, Sweden, under grant AKT-2010-018. The authors are thankful to their respective organizations for the infrastructure support.

\section{References}

Abdo Z., Schüette U.M.E., Bent S.J., Williams C.J., Forney L.J. \& Joyce P. 2006. Statistical methods for characterizing diversity of microbial communities by analysis of terminal restriction fragment length polymorphisms of $16 \mathrm{~S}$ rRNA genes. Environ. Microbiol. 8: 929-938.

ATSDR. 2008. Draft toxicological profile for cadmium, Atlanta: US Department of Health and Human Services, Agency for Toxic Substances and Disease Registry. http://www.atsdr. cdc.gov/toxprofiles/tp5-p.pdf (accessed 29.11.2015).

Barkay T. \& Pritchard H. 1988. Adaptation of aquatic microbial communities to pollutant stress. Microbiol. Sci. 5: 165-169.

Cao H., Hong Y., Li M. \& Gu J. 2012. Community shift of ammonia-oxidizing bacteria along an anthropogenic pollution gradient from the Pearl River Delta to the South China Sea. Appl. Microbiol. Biotechnol. 94: 247-259.

Dang H., Li J., Chen R., Wang L., Guo L., Zhang Z. \& Klotz M. G. 2010. Diversity, abundance, and spatial distribution of sediment ammonia-oxidizing Betaproteobacteria in response to environmental gradients and coastal eutrophication in Jiaozhou Bay, China. Appl. Environ. Microbiol. 76: 46914702.

Dávila Costa J.S., Albarracín V.H. \& Abate C.M. 2011. Responses of environmental Amycolatopsis strains to copper stress. Ecotoxicol. Environ. Safe. 74: 2020-2028.

Dudgeon D., Arthington A.H., Gessner M.O., Kawabata Z., Knowler D.J., Lévęque C. \& Eisler R. 2004. Mercury hazards from gold mining to humans, plants, and animals. Rev. Environ. Contam. Toxicol. 181: 139-198.

Eaton A.D., Clesceri L.S., Greenberg A.E. \& Franson M.A.H. 1995. Standard Methods for the Examination of Water and Wastewater. American Public Health Association., USA, $1100 \mathrm{pp}$.
Golab Z., Orlowska B., Glubiak M. \& Olejnik K. 1990. Uranium and lead accumulation in cells of Streptomyces sp. Acta Microbiol. Pol. 39: 177-188.

GSR 801 (E). 1993. General Standards for Discharge of Environmental Pollutants. EPA. http://ercmp.nic.in/Documents/ GenEnvStandard.pdf (accessed 21.09.2015)

IS 13428:2005. 2005. Bureau of Indian Standards. Packaged natural mineral water specification. https://law.resource.org/ pub/in/bis/S06/is.13428.2005.pdf (accessed 29.04.2016).

Iskandar N.L., Zainudin N.A.I.M. \& Tan S.G. 2011. Tolerance and biosorption of copper $(\mathrm{Cu})$ and lead $(\mathrm{Pb})$ by filamentous fungi isolated from a freshwater ecosystem. J. Environ. Sci. 23: 824-830.

Kent A.D., Smith D.J., Benson B.J. \& Triplett E.W. 2003. Webbased phylogenetic assignment tool for analysis of terminal restriction fragment length polymorphism profiles of microbial communities. Appl. Environ. Microbiol. 69: 6768-6776.

Kruskal J.B. 1964a. Multidimensional scaling by optimizing goodness of fit to a nonmetric hypothesis. Psychometrika 29: $1-27$.

Kruskal J.B. 1964b. Nonmetric multidimensional scaling: a numerical method. Psychometrika 29: 28-42.

Lane D.J. 1991. 16S/23S rRNA sequencing, pp 115-175. In: Stackebrandt E. \& Goodfellow M.M. (eds), Nucleic Acid Techniques in Bacterial Systematic, John Wiley \& Sons, United Kingdom.

Levinson H.S. \& Mahler I. 1998. Phosphatase activity and lead resistance in Citrobacter freundii and Staphylococcus aureus. FEMS Microbiol. Lett. 161: 135-138.

Muhammad A., Wang H.Z., Wu J.J., Xu J.M. \& Xu D.F. 2005. Changes in enzymes activity, substrate utilization pattern and diversity of soil microbial communities under cadmium pollution. J. Environ. Sci. (China) 17: 802-807.

Nakayama F.S. 1969. Theoretical consideration of the calcium sulfate-bicarbonate-carbonate interrelation in soil solution. Soil Sci. Soc. Am. J. 33: 668-672.

Nawani N., Desale P., Rahman A., Nahar N., Kapadnis B. \& Mandal A. 2016. A novel technology for the removal of metals from aqueous solutions. Indian Patent 17/MUM/2015 A. Patent Office Journal, India. 5: 4908.

PCMC. 2013. Environmental Status Report 2012-13. https:// www.pcmcindia.gov.in/pdf/esr_eng_2013.pdf (accessed 29.04. 2016).

Sheik C.S., Mitchell T.W., Rizvi F.Z., Rehman Y., Faisal M., Hasnain S., Mclnerney M.J. \& Krumholz L.R. 2012. Exposure of soil microbial communities to chromium and arsenic alters their diversity and structure. PLoS One 7: e40059.

Sunderay S.K., Panda U.C., Nayak B.B. \& Bhatta D. 2006. Multivariate statistical techniques for the evaluation of spatial and temporal variation in water quality of Mahanadi riverestuarine system (India) - a case study. Environ. Geochem. Health 28: 317-330.

Vorosmarty C.J., McIntyre P.B., Gessner M.O., Dudgeon D., Prusevich A., Green P., Glidden S., Bunn S.E., Sullivan C.A., Reidy Liermann C. \& Davies P.M. 2010. Global threats to human water security and river biodiversity. Nature 467: 555561.

Yebra D.M., Kill S. \& Dam-Johansen K. 2004. Anti-fouling technology: past, present and future steps towards efficient and environmentally friendly antifouling coatings. Progr. Org. Coat. 50: 75-104. 